\title{
Comparison of Estimated Power Transfer in Transmission Line With and Without Shunt Compensator Using Different Line Models
}

\author{
Sincy Elezebeth Kuruvilla, M Arunachalam
}

\begin{abstract}
In power systems, compensation techniques are used to improve the power transfer capacity in the transmission lines. Controlling the voltage profile along the line helps to control the transmittable power and this is achieved through compensation techniques. In this paper, different line models are used for the estimated power transmitted in the line both with and without shunt compensation. It is observed that with the Bergeron line model and PI-section model the estimated power is higher compared to that with the series RL model both with and without shunt compensation. PSCAD is used for the simulation.
\end{abstract}

Keywords : Bergeron model, PI-Section, Power Angle Curve, Shunt compensation, Transmission line.

\section{INTRODUCTION}

$T_{\text {he transmittable power over a long transmission line }}$ can be increased by employing synchronous compensators at the load centres or throughout the length of the transmission lines. Static Var compensators are employed at transmission level as local continuous stability controls and capacitor/ reactor banks are employed as local discontinuous controls for reactive power compensation. The practical maximum transmittable power of a transmission line includes not only the capacity in kilovolt-amperes but also in the change of reactive power for a definite change in voltage.

The reactance of the transmission circuit is indirectly proportional to the size of the conductor, whereas the conductivity is directly proportional. Generally, the transmittable power limit of a transmission line can be enhanced by employing large conductors or large voltages which is not economical with the higher cost of line. The closer the spacing of the conductor, the greater effects on the power limits [1]. However, it's not a practical method as it leads to the interruption to the service.

The studies show that the shunt compensators at various intermediate points of transmission lines maintain steady voltages at these points and increase the power transfer capacity of the system. Also, the frequency of the supply has significant effect on the large amounts of power transmission [1].

The security and reliability of a transmission system can be achieved through fast control of system parameters. The FACTS (Flexible AC Transmission Systems) devices which

Revised Manuscript Received on March 5, 2020.

* Correspondence Author

Sincy Elezebeth Kuruvilla*, School of Electrical Engineering, VIT University, Vellore, TamilNadu, India. Email: sincyek@gmail.com

M Arunachalam, School of Electrical \& Electronics Engineering,REVA University, Bangalore, India. Email: arunachalammalaiyandi@yahoo.co.in employ Power Electronics converters help to achieve the objective of transmission system security and reliability [2],[3],[4]. Shunt connected FACTS devices help to increase the capacity of the transmission system by regulating the voltage and by exchanging active power and reactive power with the grid [5],[6],[7]. This aspect helps to integrate the renewable energy sources to the grid [7],[8].

Although PI-section transmission models are extensively used, it has drawbacks of resulting in oscillations due to the lumped parameters [9]. Several solutions have been developed and post processing filters methodology is proposed to attenuate the oscillations [10]. It is found to be more efficient than the traditional methods.

This paper is arranged as follows: Section II covers voltage regulation for midpoint and one third of transmission line segmentation. Different models of transmission lines are explained in Section III. The simulation study and the comparison of results are tabulated in Section IV. Observations are concluded in Section V.

\section{VOLTAGE REGULATION FOR LINE SEGMENTATION}

Presently, majority of transmission lines are operated much below their thermal limit. Therefore, the distribution of power flow among different transmission lines involved suitably can result in lower transmission losses. It is difficult to have such optimum power flow among different transmission line without employing FACTS devices at different strategies. The improper distribution of power makes the transmission system very congested. With every increase in demand of electric power, there is about 10 to $15 \%$ shortage in meeting the load demand due to constraints in the transmittable power in the transmission line. Therefore upgradation of transmission network is needed.

Constructing Constructing new transmission lines are expensive and it is difficult to complete within the time limit. Hence to improve the transmittable power of the lines; to regulate the congestion in the transmission systems and to improve the steady voltage in the system, advanced compensators are needed. The compensators can regulate the flow of power in the system.

Fig. 1 shows simple two area transmission network with the transmission line represented by lumped inductance. The resistance of the line is neglected. The midpoint shunt compensation regulates the midpoint voltage to a level 


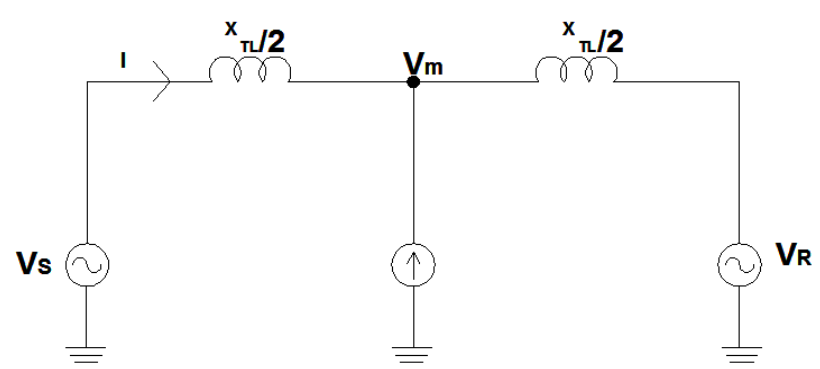

Fig. 1. Two area Transmission network with mid-point shunt compensation

close to the terminal voltage. The Fig. 2 shows the vector diagram. While injecting the reactive current into the system, the voltage profile at the connected point is regulated resulting in enhancement of transmittable power [11].

The transmitted power is given by (1)

$$
P=2 \frac{V^{2}}{X_{T L}} \sin \left(\frac{\delta}{2}\right)
$$

and the reactive power is given by (2)

$$
Q=4 \frac{V^{2}}{X_{T L}}\left(1-\cos \frac{\delta}{2}\right)
$$

The theory of segmentation of transmission line can be expanded by the use of multiple compensators, located at one third and two third of the transmission line. It is explained for three equal line sections in Fig. 3 and its associated phasor diagram is given in Fig. 4.

The transmitted active power, when compensator is connected at $1 / 3^{\text {rd }}$ and $2 / 3^{\text {rd }}$ location of transmission line is given by (5). The reactive power supplied by the compensator at $1 / 3^{\text {rd }}$ and $2 / 3^{\text {rd }}$ of transmission line is given by (9) and (10) respectively.

$\mathrm{V}_{\mathrm{SA}}, \mathrm{V}_{\mathrm{AB}}, \quad \mathrm{V}_{\mathrm{BR}}$ are the voltage drops across the corresponding sections of the line. The vector $\mathrm{V}_{\mathrm{SA}}$ is given by (3). Neglecting the line resistance, the current flowing through the line sections are given by (7).

$$
V_{S A}=V_{S}-V_{A}=j \frac{X}{3} I_{A S}
$$

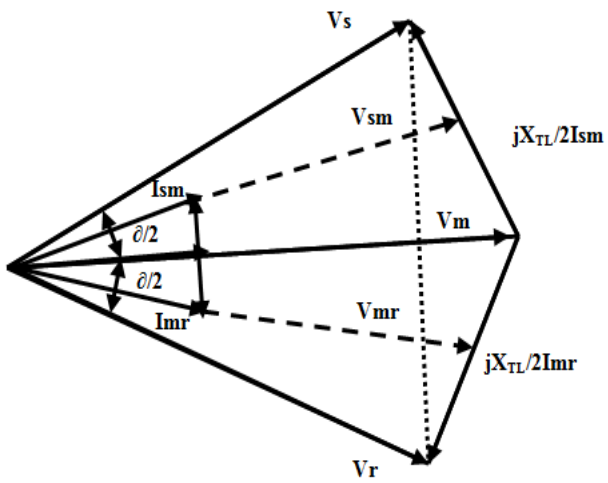

Fig. 2. Phasor diagram of midpoint shunt compensation

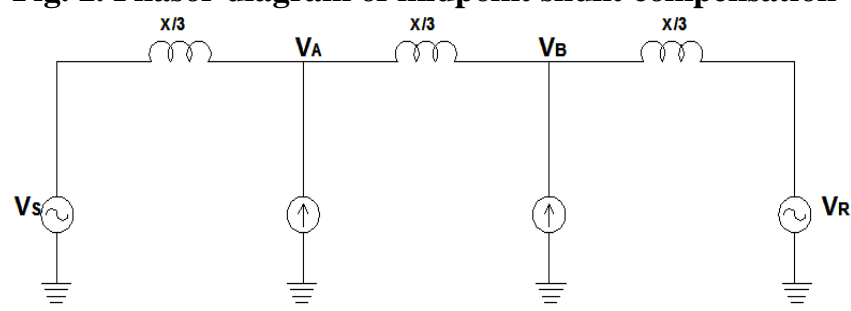

Fig. 3. Transmission network with shunt compensators at $1 / 3$ rd and $2 / 3$ rd of the line

Power transmitted,

$$
\begin{aligned}
& P=\frac{\left|V_{S}\right|\left|V_{A}\right|}{X / 3} \sin \left(\frac{\delta}{3}\right)=\frac{3 V^{2}}{X} \sin \left(\frac{\delta}{3}\right) \\
& V_{S A}=V_{A B}=V_{B R}=V \cos \left(\frac{\delta}{3}\right) \\
& I_{A S}=I_{B A}=I_{R B}=I=\frac{6 V}{X} \sin \left(\frac{\delta}{6}\right)
\end{aligned}
$$

$\mathrm{Q}$ supplied by the compensator connected at A,

$$
Q_{A}=V\left[I_{A S} \sin \left(\frac{\delta}{6}\right)+I_{B A} \sin \left(\frac{\delta}{6}\right)\right]=2 V I \sin \left(\frac{\delta}{6}\right)
$$

Substituting the value of I from (7)

$$
Q_{A}=\frac{6 V^{2}}{X}\left[1-\cos \left(\frac{\delta}{3}\right)\right]
$$

Similarly, Q supplied by the compensator connected at B,

$$
Q_{B}=\frac{6 V^{2}}{X}\left[1-\cos \left(\frac{\delta}{3}\right)\right]
$$

The power angle curve without compensator; with shunt compensator at mid-point and one-third location of transmission line is plotted in Fig. 5. The transmission line

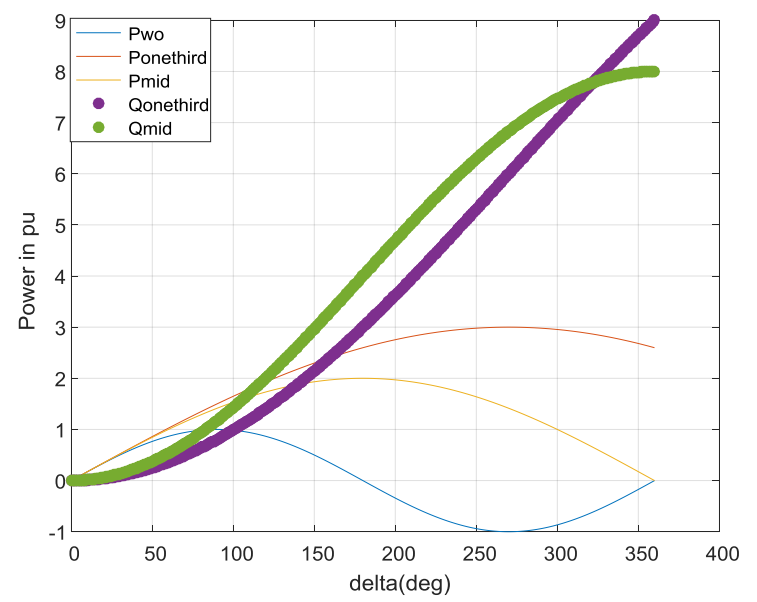

Fig. 5. Power Angle Curve with and without shunt compensator at midpoint, 1/3rd and 2/3rd of the transmission line considering line as a lumped reactance.

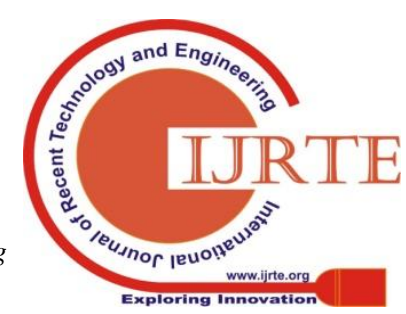


voltage of $400 \mathrm{kV}$ and lumped line reactance of $157.85 \Omega / \mathrm{km}$ is considered. Fig. 5 depicts that without compensation, the maximum power will be transmitted at delta $=90^{\circ}$ [12]. At mid-point compensation, maximum power will be transmitted at delta $=180^{\circ}$ as in (1). At one-third compensation, maximum power will be transmitted at delta $=$ $270^{\circ}$ as in (5). It is observed that the shunt compensators placed at equal segments of the transmission line can increase the capacity of power transmission at the expense of a rapidly escalating reactive power demand on the shunt compensators.

\section{DIFFERENT MODELS OF TRANSMISSION LINE}

In Section II, lumped inductance is considered for the simplicity of analysis to show the importance of shunt compensation in enhancing the transmittable power limit of the line. In this section lumped parameters of the respective model of transmission line is considered.

\section{A. Series RL Representation of Transmission Line}

The short line can be represented by lumped series impedance as shown in Fig. 6. The shunt capacitance for this case is negligible. For ' $l$ ' $\mathrm{km}$ length of line, the line impedance per $\mathrm{km}$ is $z_{0}=(r+j x)$, then the total impedance of the line is $Z=(R+j X)$. The sending end voltage, $V s$ and current, $I s$ is given by (11) and (12) respectively.

$$
\begin{aligned}
& V_{S}=V_{R}+Z I_{R} \\
& I_{S}=I_{R}
\end{aligned}
$$

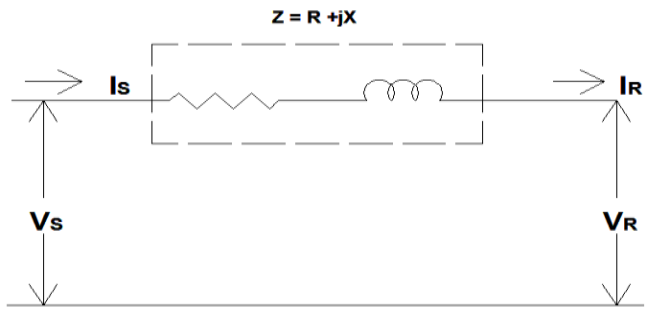

Fig. 6. Series RL representation of transmission line

\section{B. PI Section ( $\Pi$ - Section)}

The short overhead lines are represented by using PImodel. It characterize transmission systems for load flow studies under steady state in a better way. The Coupled PI sections are used to represent the transmission lines.

- Coupled PI-Section: The Coupled PI-section of transmission line is given by using lumped passive elememts of $R, L$ and $C$ as in Fig. 7. The coupling between the three phases are provided by $R$ and $L$ elements [13]. $\mathrm{C}$ is distributed as a mutual capacitance and $\mathrm{Cm}$ as a capacitance to ground at each end as in Fig. 7.

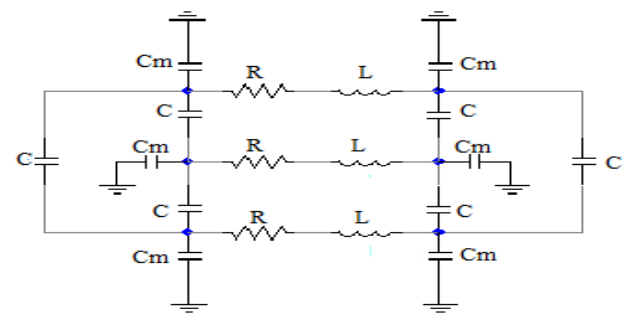

Fig. 7. Coupled PI-Section model of TL

\section{Bergeron Model}

The Bergeron model is a distributed LC parameter model with $1 / 2$ resistance in the middle and $1 / 4^{\text {th }}$ of that at each end of the transmission line [13]. It is a single frequency model and used to represent long transmission lines. As the line resistance is included in this model, it helps to damp the oscillation. The $\mathrm{L}$ and $\mathrm{C}$ elements of the model are distributed as of a PI section. This model is applicable for transient studies [14], relay studies, and load flow studies where fundamental frequency is important.

\section{SYSTEM STUDY}

In this paper, the transmission line is simulated in PSCAD using three different models and the power transfer capacity is compared. The parameters for transmission line under study are adopted from India's first series compensated Kanpur-Ballabhgarh 400kV transmission line (400km) [15]. Shunt capacitors are connected at intermediate points to improve the voltage stability and higher power transmission capability. The transmission line parameters are as follows:

Positive sequence parameters:

$\mathrm{L}=1.044 \mathrm{mH} / \mathrm{km}, \mathrm{C}=16 \mathrm{nF} / \mathrm{km}, \mathrm{R}=0.0296 \Omega / \mathrm{km}$

Zero sequence parameters:

$\mathrm{L}=3.259 \mathrm{mH} / \mathrm{km}, \mathrm{C}=9 \mathrm{nF} / \mathrm{km}, \mathrm{R}=0.2986 \Omega / \mathrm{km}$

In study system 1 , shunt compensator is connected at $200 \mathrm{~km}$ i.e., at the mid-point of the transmission line. The steady state performance of the transmission line is simulated under various sending end angle, delta. The estimated power transmit capability of the three models of transmission line with midpoint shunt compensation for various sending angle, delta is compared in Table I and power angle curve is plotted in Fig. 8 .

In study system 2 , shunt compensator is connected at $1 / 3 \mathrm{rd}$ and $2 / 3$ rd of the

Table- I: Comparison of estimated power transfer in three different models of transmission lines with

\begin{tabular}{|c|c|c|c|c|c|}
\hline $\begin{array}{l}\text { Tr. Line } \\
\text { Model }\end{array}$ & Particulars & $\begin{array}{c}\text { Delta } \\
\text { (degre } \\
\text { es) }\end{array}$ & $\begin{array}{c}\mathbf{Q c}^{\mathrm{a}} \\
\text { (MVAr) }\end{array}$ & $\begin{array}{c}\mathbf{P}_{\mathbf{R}}^{\mathbf{b}^{\mathbf{b}}} \\
(\mathbf{M W})\end{array}$ & $\begin{array}{l}\mathbf{V}_{\text {pu }}{ }^{c} \\
(\mathbf{p u})\end{array}$ \\
\hline \multirow{6}{*}{$\begin{array}{l}\text { Series } \\
\text { RL } \\
\text { model }\end{array}$} & $\begin{array}{c}\text { With } \\
\text { compensator }\end{array}$ & 30 & 138.9 & 512.6 & 1 \\
\hline & $\begin{array}{c}\text { Without } \\
\text { compensator }\end{array}$ & 30 & - & 494.8 & 0.9659 \\
\hline & $\begin{array}{c}\text { With } \\
\text { compensator }\end{array}$ & 60 & 550.8 & 971.3 & 1 \\
\hline & $\begin{array}{c}\text { Without } \\
\text { compensator }\end{array}$ & 60 & - & 836.6 & 0.866 \\
\hline & $\begin{array}{c}\text { With } \\
\text { compensator }\end{array}$ & 90 & 1199 & 1344 & 1 \\
\hline & $\begin{array}{c}\text { Without } \\
\text { compensator }\end{array}$ & 90 & - & 934 & 0.7071 \\
\hline \multirow{6}{*}{$\begin{array}{c}\text { PI } \\
\text { section }\end{array}$} & $\begin{array}{c}\text { With } \\
\text { compensator }\end{array}$ & 30 & 6.039 & 610.7 & 1 \\
\hline & $\begin{array}{c}\text { Without } \\
\text { compensator }\end{array}$ & 30 & - & 614.5 & 0.998 \\
\hline & $\begin{array}{c}\text { With } \\
\text { compensator }\end{array}$ & 60 & 502.7 & 1153 & 1 \\
\hline & $\begin{array}{c}\text { Without } \\
\text { compensator }\end{array}$ & 60 & - & 1038 & 0.8953 \\
\hline & $\begin{array}{c}\text { With } \\
\text { compensator }\end{array}$ & 90 & 1286 & 1588 & 1 \\
\hline & $\begin{array}{c}\text { Without } \\
\text { compensator }\end{array}$ & 90 & & & 0.7311 \\
\hline
\end{tabular}
midpoint shunt compensation 
Comparison of Estimated Power Transfer in Transmission Line With and Without Shunt Compensator Using Different Line Models

\begin{tabular}{|c|c|c|c|c|c|}
\hline $\begin{array}{l}\text { Tr. Line } \\
\text { Model }\end{array}$ & Particulars & $\begin{array}{c}\text { Delta } \\
\text { (degre } \\
\text { es) }\end{array}$ & $\begin{array}{c}\mathbf{Q c}^{\mathrm{a}} \\
(\mathbf{M V A r})\end{array}$ & $\begin{array}{c}\mathbf{P}_{\mathbf{R}}^{\mathbf{b}} \\
(\mathbf{M W})\end{array}$ & $\begin{array}{l}\mathbf{V}_{\text {pu }}^{c} \\
(\mathbf{p u})\end{array}$ \\
\hline \multirow{6}{*}{$\begin{array}{l}\text { Bergero } \\
\mathrm{n} \text { model }\end{array}$} & $\begin{array}{c}\text { With } \\
\text { compensator }\end{array}$ & 30 & 18.2 & 618.7 & 1 \\
\hline & $\begin{array}{c}\text { Without } \\
\text { compensator }\end{array}$ & 30 & - & 616.4 & 0.9986 \\
\hline & $\begin{array}{c}\text { With } \\
\text { compensator }\end{array}$ & 60 & 516.3 & 1167 & 1 \\
\hline & $\begin{array}{c}\text { Without } \\
\text { compensator }\end{array}$ & 60 & - & 1038 & 0.8953 \\
\hline & $\begin{array}{c}\text { With } \\
\text { compensator }\end{array}$ & 90 & 1296 & 1604 & 1 \\
\hline & $\begin{array}{c}\text { Without } \\
\text { compensator }\end{array}$ & 90 & - & 1151 & 0.73 \\
\hline
\end{tabular}

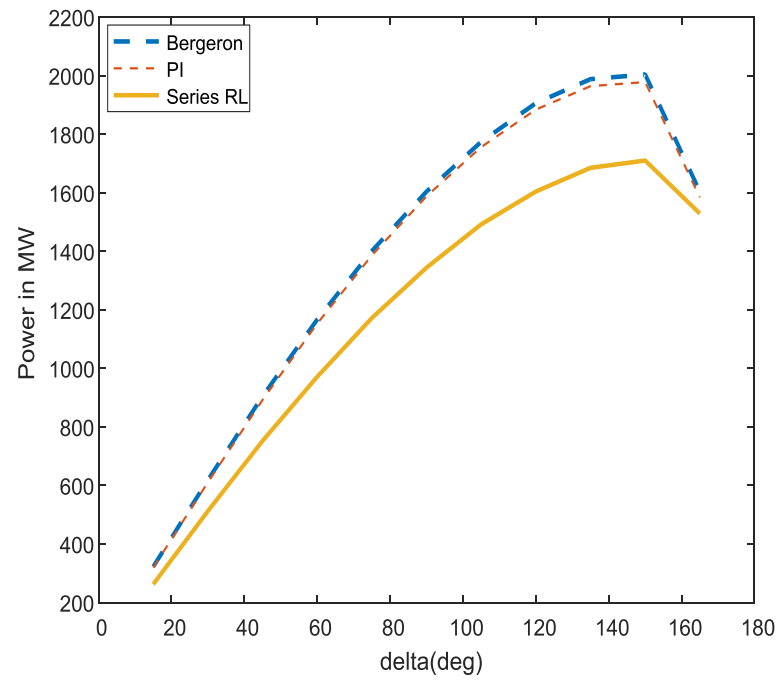

Fig. 8. Power angle curve for three different line models with shunt capacitor at midpoint of the transmission line

transmission line. Table II compares the transmitted power of three different models of transmission line with $1 / 3 \mathrm{rd}$ and $2 / 3$ rd shunt compensation. Its power angle curve is plotted in Fig. 9.

Fig. 8 and 9 show that, the compensated PI-section model and Bergeron model of transmission lines transmit higher power than the compensated series RL model by regulating

Table- II: Comparison of estimated power transfer in three different models of transmission lines with $1 / 3$ rd and 2/3rd shunt compensation

\begin{tabular}{|c|c|c|c|c|c|}
\hline $\begin{array}{l}\text { Tr. Line } \\
\text { Model }\end{array}$ & Particulars & $\begin{array}{c}\text { Delta } \\
\text { (degre } \\
\text { es) }\end{array}$ & $\begin{array}{c}\mathbf{Q c}^{\mathrm{a}} \\
\text { (MVAr) }\end{array}$ & $\begin{array}{c}\mathbf{P}_{\mathbf{R}}{ }^{\mathbf{b}} \\
(\mathbf{M W})\end{array}$ & $\begin{array}{l}\mathbf{V}_{\text {pu }}{ }^{c} \\
(\mathbf{p u})\end{array}$ \\
\hline \multirow{6}{*}{$\begin{array}{l}\text { Series RL } \\
\text { model }\end{array}$} & \multirow{2}{*}{$\begin{array}{c}\text { With } \\
\text { compensato } \\
\text { r }\end{array}$} & \multirow{2}{*}{30} & 95.53 & \multirow{2}{*}{516.5} & \multirow{2}{*}{1} \\
\hline & & & 95.58 & & \\
\hline & $\begin{array}{c}\text { Without } \\
\text { compensato } \\
\text { r }\end{array}$ & 30 & - & 494.7 & 0.9698 \\
\hline & \multirow{2}{*}{$\begin{array}{c}\text { With } \\
\text { compensato } \\
\text { r }\end{array}$} & \multirow{2}{*}{60} & 381.2 & \multirow{2}{*}{997.7} & \multirow{2}{*}{1} \\
\hline & & & 363.3 & & \\
\hline & $\begin{array}{c}\text { Without } \\
\text { compensato } \\
\mathrm{r}\end{array}$ & 60 & - & 836.6 & 0.8819 \\
\hline \multirow{5}{*}{ PI section } & \multirow{2}{*}{$\begin{array}{c}\text { With } \\
\text { compensato } \\
\mathrm{r} \\
\end{array}$} & \multirow[b]{2}{*}{30} & 6.04 & \multirow{2}{*}{615.9} & \multirow[b]{2}{*}{1} \\
\hline & & & 6.04 & & \\
\hline & $\begin{array}{c}\text { Without } \\
\text { compensato } \\
\text { r }\end{array}$ & 30 & - & 614.5 & 0.99 \\
\hline & \multirow{2}{*}{$\begin{array}{c}\text { With } \\
\text { compensato } \\
\text { r }\end{array}$} & \multirow{2}{*}{60} & 344.7 & \multirow{2}{*}{1187} & \multirow[b]{2}{*}{1} \\
\hline & & & 340.3 & & \\
\hline
\end{tabular}

\begin{tabular}{|c|c|c|c|c|c|}
\hline $\begin{array}{c}\text { Tr. Line } \\
\text { Model }\end{array}$ & Particulars & $\begin{array}{c}\begin{array}{c}\text { Delta } \\
\text { (degre } \\
\text { es) }\end{array} \\
\end{array}$ & $\begin{array}{c}\mathbf{Q c}^{\mathrm{a}} \\
\text { (MVAr) }\end{array}$ & $\begin{array}{c}\mathbf{P}_{\mathbf{R}}^{{ }^{b}} \\
(\mathbf{M W})\end{array}$ & $\begin{array}{l}\mathbf{V}_{\text {pu }}{ }^{\mathbf{c}} \\
(\mathbf{p u})\end{array}$ \\
\hline & $\begin{array}{c}\text { Without } \\
\text { compensato } \\
\mathrm{r}\end{array}$ & 60 & - & 1035 & 0.91 \\
\hline & With & & 934.2 & & \\
\hline & $\begin{array}{c}\text { compensato } \\
\mathrm{r}\end{array}$ & 90 & 838.4 & 1695 & 1 \\
\hline & $\begin{array}{c}\text { Without } \\
\text { compensato } \\
\mathrm{r}\end{array}$ & 90 & - & 1149 & 0.765 \\
\hline \multirow{9}{*}{$\begin{array}{l}\text { Bergeron } \\
\text { model }\end{array}$} & \multirow{2}{*}{$\begin{array}{c}\text { With } \\
\text { compensato } \\
\mathrm{r}\end{array}$} & \multirow{2}{*}{30} & 6.04 & \multirow{2}{*}{617.6} & \multirow{2}{*}{1} \\
\hline & & & 6.04 & & \\
\hline & $\begin{array}{c}\text { Without } \\
\text { compensato } \\
\text { r }\end{array}$ & 30 & - & 616.2 & 0.99 \\
\hline & \multirow{2}{*}{$\begin{array}{c}\text { With } \\
\text { compensato } \\
\text { r }\end{array}$} & \multirow[b]{2}{*}{60} & 344.2 & \multirow[b]{2}{*}{1189} & \multirow[b]{2}{*}{1} \\
\hline & & & 399.8 & & \\
\hline & $\begin{array}{c}\text { Without } \\
\text { compensato } \\
\mathrm{r}\end{array}$ & 60 & - & 1038 & 0.91 \\
\hline & \multirow{2}{*}{$\begin{array}{c}\text { With } \\
\text { compensato } \\
\text { r }\end{array}$} & \multirow{2}{*}{90} & 931.4 & \multirow{2}{*}{1696} & \multirow[b]{2}{*}{1} \\
\hline & & & 844.1 & & \\
\hline & $\begin{array}{c}\text { Without } \\
\text { compensato } \\
\text { r }\end{array}$ & 90 & - & 1150 & 0.76 \\
\hline
\end{tabular}

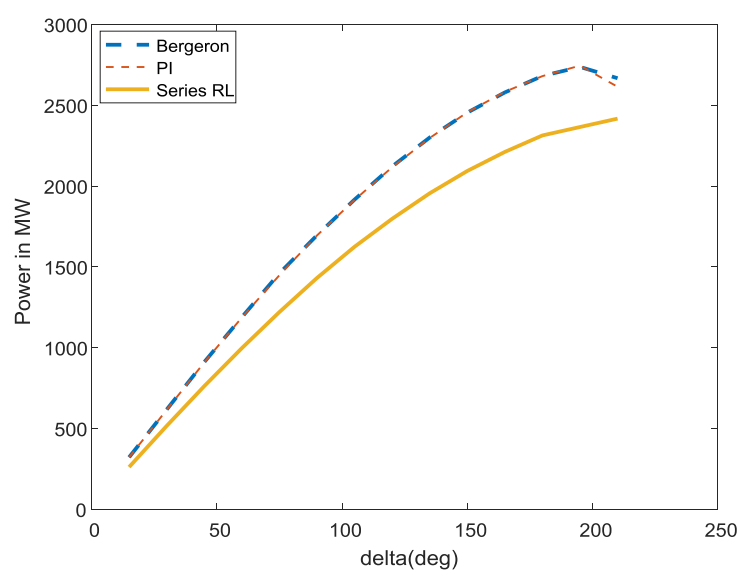

Fig. 9 Power angle curve for three different line models with shunt capacitor at $1 / 3$ rd and $2 / 3$ rd of the transmission line

the voltage at point of connection to $1.0 \mathrm{pu}$. The negative direction of the estimated power transfer indicates power flow in the reverse direction. Comparison of the maximum transmitted power of three different line models is shown in Table III. The transmittable power capability of transmission line can be improved by shunt compensators at various locations which segment the transmission line equally. Table III shows that in the PI section and Bergeron model of transmission lines, the midpoint compensation increases the maximum transmitted power by 1.6 times as well as the one -third compensation by 2.4 times than that of the uncompensated transmission line of like models. The single line diagram of simulation of three different models of transmission line without and with shunt compensation at different locations is shown in Fig. 10 to 12.

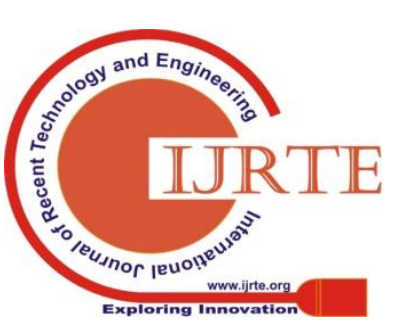


Table- III: Comparison of maximum transmitted power in three different models of transmission line

\begin{tabular}{|c|c|c|}
\hline \multirow{2}{*}{$\begin{array}{c}\text { Tr. Line } \\
\text { Model }\end{array}$} & $\begin{array}{c}\text { Location of } \\
\text { Compensator }\end{array}$ & $\begin{array}{c}\text { Maximum } \\
\text { transmitted power, } \\
\text { Pmax (MW) }\end{array}$ \\
\hline \multirow{2}{*}{ Bergeron } & Uncompensated & 1151 \\
\cline { 2 - 3 } & Midpoint & 1604 \\
\cline { 2 - 3 } & $1 / 3^{\text {rd }}, 2 / 3$ rd & 2668 \\
\hline PI section & Uncompensated & 1139 \\
\hline
\end{tabular}

\begin{tabular}{|l|c|c|}
\hline \multirow{2}{*}{$\begin{array}{c}\text { Tr. Line } \\
\text { Model }\end{array}$} & $\begin{array}{c}\text { Location of } \\
\text { Compensator }\end{array}$ & $\begin{array}{c}\text { Maximum } \\
\text { transmitted power, } \\
\text { Pmax (MW) }\end{array}$ \\
\hline \multirow{2}{*}{\begin{tabular}{c}
\multirow{2}{*}{$\begin{array}{l}\text { Series RL } \\
\text { model }\end{array}$} \\
\cline { 2 - 3 }
\end{tabular}} & Midpoint & 1584 \\
\cline { 2 - 3 } & $1 / 3^{\text {rd }}, 2 / 3 \mathrm{rd}$ & 2615 \\
\cline { 2 - 3 } & Uncompensated & 934 \\
\hline
\end{tabular}

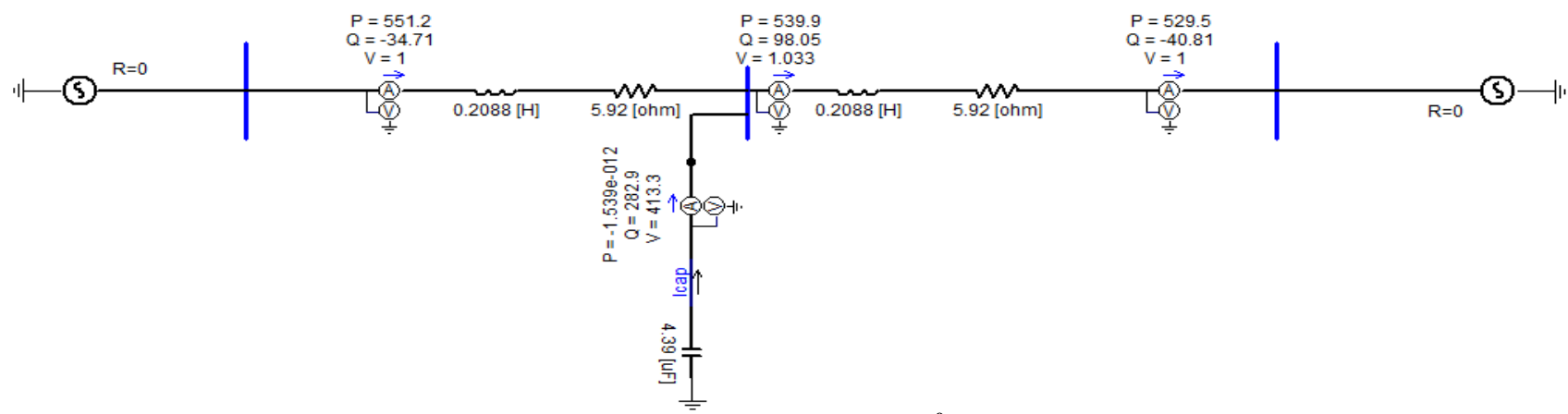

Fig. 10. Series RL model of transmission line for delta $=30^{0}$ with midpoint shunt compensator

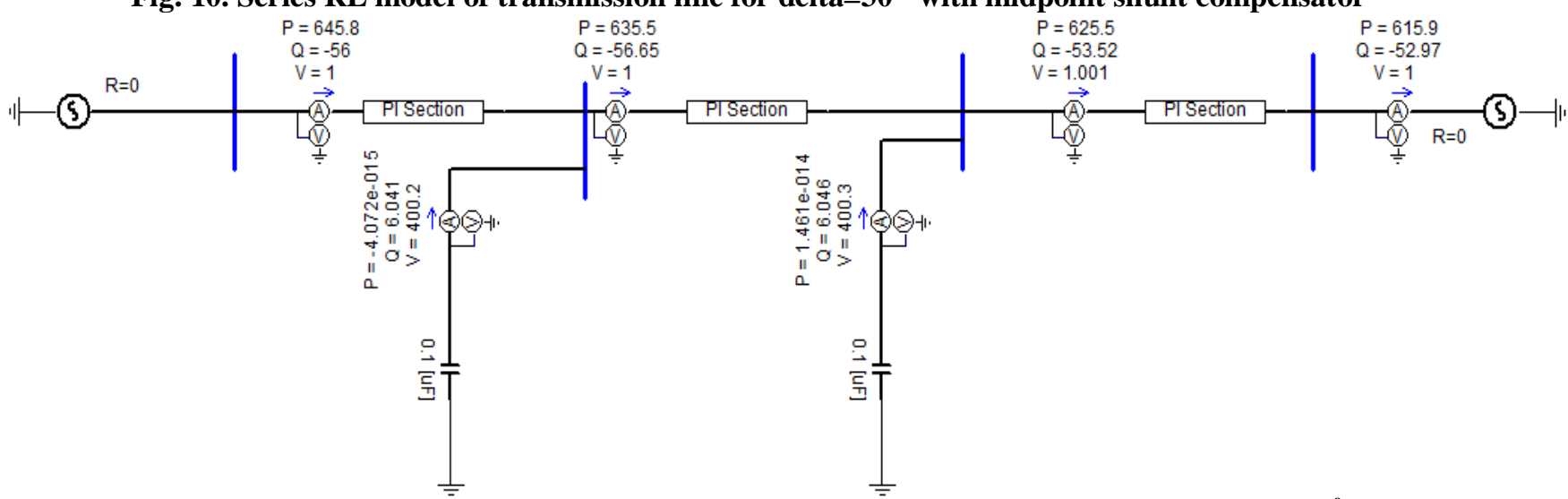

Fig. 11. PI section model with shunt compensator at $1 / 3 \mathrm{rd}$ and $2 / 3 \mathrm{rd}$ of $\mathrm{TL}$ for delta $=30^{\circ}$

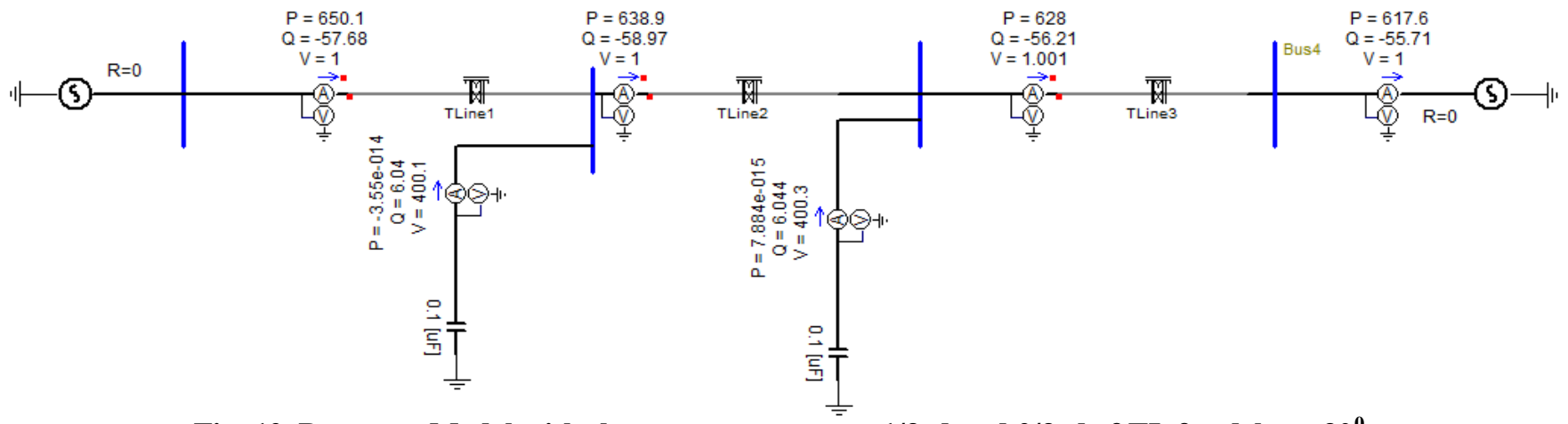

Fig. 12. Bergeron Model with shunt compensator at 1/3rd and 2/3rd of TL for delta $=30^{0}$

\section{CONCLUSION}

In this paper, estimated power transfer capability of three different line models of transmission line with shunt compensators located at equal segments is compared with uncompensated transmission line. The shunt compensators connected at the intermediate point's injected reactive power to regulate the midpoint voltage and thereby improve the transmittable power limit of the line. The PI-Section and Bergeron model of transmission lines with suitable value of shunt capacitors give higher estimated transmittable power than Series RL model of line.

Multiple shunt compensators enhance the maximum transmittable power of transmission line to an extent.

\section{REFERENCES}

1. R. D. Evans, H. K. Sels, "Power Limitations of Transmission Systems", Journal of the A.I.E.E, Vol. 43, Issue 1, 1924, pp 45-51

2. M. H. Haque, "Stability Improvement by FACTS Devices: A comparison between STATCOM and SSSC", IEEE Power Engineering SocietyGeneral Meeting, June 2005, Print ISSN 1932-5517. 


\section{Comparison of Estimated Power Transfer in Transmission Line With and Without Shunt Compensator Using Different Line Models}

3. M. Shafiul Alam, Md.Abdur Razzak, Md. Nazmul Hasan, "Transmission capacity Enhancement of East West Interconnectors using series shunt compensation", 7th International Conference on Electrical and Computer Engineering, pp 579-582, 2012.

4. M. Venkateshwara Rao, S. Sivanagaraju, Chintalapudi V Suresh, "Available transfer capability evaluation and enhancement using various FACTS controllers: Special focus on system security”, Ain Shams Engineering Journal, Vol 7, Issue 1, March 2016, pp 191-207.

5. Esther Barrios, Cesar Angeles, "Technical comparison of FACTS controllers in parallel connection", Journal of Applied Research and Technology, Feb - 2017, Vol. 15, Issue 1, pp 36-44.

6. Mohd. Azharuddin, S. R. Gaigowal, "Voltage Regulation by grid connected PV-STATCOM”, IEEE Conf., March - 2017.

7. Sridhar Bala Subramanian, Sibin Mohan, Mohammad Akbari, Hesamaldin Maleki, Reza Salehi, Wayne H. Litzenberger (Vice Chair), and Rajiv K. Varma (Chair), "Control Of STATCOMs - A Review", IEEE Power and Energy Society General Meeting (PESGM), December - 2018.

8. Saraswathi Ananthavel, Sanjeevikumar Padmanabhan, Sutha Shanmugham, Frede Blaabjerg, Ahmet H Ertas, Viliam Fedak, "Analysis of enhancement in available power transfer capacity by STATCOM integrated SMES by numerical simulation studies", Engineering Science and Technology, an International Journal, Vol. 19, Issue 2, June 2016, pp 671-675.

9. E. C. M. da Costa, S. Kurokawa, A. A. Shinoda, J. Pissolato, "Digital filtering of oscillations intrinsic to transmission line modeling based on lumped parameters," Int. Electr. Power Energy Syst., vol. 44, pp. 908-915, 2013

10. Andreas I. Chrysochos, Georgios P. Tsolaridis, Theofilos A. Papadopoulos, and Grigoris K. Papagiannis, "Damping of Oscillations Related to Lumped-Parameter Transmission Line Modeling," Research Gate, Conference paper -2015.

11. Narain G Hingorani, Laszio Gyugi, "Understanding Facts: Concepts and Technology of Flexible AC Transmission Systems", IEEE Power Engineering Society, John Wiley and Sons, Inc., Publication.

12. DebashishMondal, Abhijit Chakrabarti, Aparajita Sengupta, "Chapter 7 - Application of FACTS Controller", Power System Small Signal Stability Analysis and Control, 2014, pp -185 - 225.

13. https://hvdc.ca/webhelp/PSCAD/Transmission_Lines_and_Cables/ Transmission_Lines_and_Cables.htm

14. Naret Suyaroj, Suttichai Premrudeepreechacharn, Neville Robert Watson, "Transient state estimation with the Bergeron transmission line model," Turk J Elec Eng \& Comp Sci 25: 806-819, 2017.

15. M.Arunachalam, GhammandiLal, C.G. Rajiv, M.M.Babu Narayanan,"Performance Evaluation of TCSC Control and Protection Equipment using RTDS", 15th Power System Computation Conference (PSCC), August 2006.

\section{AUTHORS PROFILE}

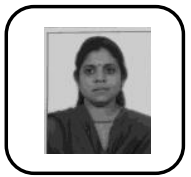

Sincy Elezebeth Kuruvilla (M' 2016) graduated B.Tech in Electrical \& Electronics Engineering from Mar Athanasius College of Engg., M G University, Kerala in the year 2002. She completed her PG in Applied Electronics from Annai University, Coimbatore in the year 2010. She has a total teaching experience of 11 years. She is pursuing her $\mathrm{PhD}$ in VIT University, Vellore. Her area of interest is Application of Power Electronics in Power Systems.

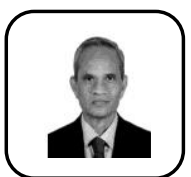

M. Arunachalam (SM' 2006) received B.E. Electrical Engineering and M.Sc (Engg) in Power System Engg from Madras University in the year 1970 and 1972 respectively. He obtained Ph.D from IIT Kanpur in 1978. He is currently associated with School of Electrical and Electronics Engineering Department of REVA University, Bangalore. He was working as a Professor and Head of the Department of Electrical and Electronics Engineering of Rajarajeswari College of Engineering, Bangalore from Jan 2013 to Jan 2018. Prior to this, he was working with Electronics Division of Bharat Heavy Electricals Limited (BHEL), Bangalore, India from 1978 -2008. During his service in BHEL, he was a General Manager at the time of his superannuation and he continued at BHEL as a Senior Specialist from 2008 till 2012 in the area of HVDC and FACTS. His research interests include High Power Converters and Controls for HVDC and FACTS. He is a member of various National committees and International working groups (CIGRE). He received an innovative project award for the project "Development of controller for TCSC" in 2013. He is the co-inventor in seven patents, out of which six has already been granted. He has got 34 years of industrial experience in Product design, Engineering and Development as well as 7 years experience in teaching. 